\title{
PENGARUH METODE PEMBELAJARAN DEMONSTRASI TERHADAP \\ HASIL BELAJAR PADA MATA KULIAH BAHASA INDONESIA MAHASISWA PGSD UNIV. QUALITY MEDAN \\ TAHUN AKADEMIK 2019-2020
}

\author{
Gemala Widiyarti \\ Dosen Prodi Pendidikan Guru Sekolah Dasar Universitas Quality \\ widiyartigemala@gmail.com
}

\begin{abstract}
Abstrak : Penelitian ini dilakukan dengan tujuan untuk mengetahui pengaruh hasil belajar mahasiswa dalam materi EYD dengan menggunakan pembelajaran Metode Demonstrasi dengan Pembelajaran Konvesional di semester 1 mahasiswa PGSD Universitas Quality Medan. Jenis penelitian ini adalah quasi eksperimen dengan instrumen test essay sebanyak 3 soal yang telah divalidasi oleh validator. Sebelum melakukan pembelajaran hasil rata-rata tes awal kelas $2 \mathrm{~A} 22=48,57$ dan rata-rata hasil belajar $\mathrm{Vb}=47,14$. Setelah dilaksanakan pembelajaran pada kelas 2A22 dengan menggunakan Metode Demonstrasi dan setelah dilakukan tes akhir siswa memperoleh rata-rata 80,13 sedangkan hasil belajar pada kelas 2A23 dengan menggunakan Pembelajaran Konvesional memperoleh rata-rata 74,95. Berdasarkan perhitungan ujii hipotesis dengan uji bk untuk data kelas 2A22 dengan metode Demonstrasi dan kelas 2A23 dengan pembelajaran Konvesional diperoleh $X_{\text {hitung }}\left(X^{2}\right)=33,03$ dan $X_{\text {tabel }}=5,99$ Jadi nilai $X_{\text {hitung lebih besar dari }}$ pada $X_{\text {tabel }}$. Kesimpulan dalam penelitian ini adalah hasil belajar siswa dengan menggunakan metode Demonstrasi diperoleh diperoleh nilai rata-rata 80,13, hasil belajar siswa dengan pembelajaran konvensional diperoleh rata-rata 74,95, Hasil belajar siswa dengan menggunakan Metode Demonstrasi berpengaruh secara signifikan terhadap hasil belajar siswa pada mata pelajaran Bahasa Indonesia semester 1 mahasiswa PGSD, hasil belajar dengan menggunakan konvensional kurang signifikan karana cara belajar menggunakan Kovensional kurang menarik pada belajar untuk Mahasiswa di semester 1 PGSD Universitas Quality Medan Tahun akademik2019-2020.
\end{abstract}

Kata Kunci : Metode Demonstrasi, Pembelajaran Konvesional, Hasil Belajar, Bahasa Indonesia.

\section{PENDAHULUAN}

Pendidikan tak lepas dari dosen, mahasiswa, sarana dan prasarana serta hal nya hasil belajar sebagai output pembelajaran. Dosen dan mahasiswa merupakan faktor penting dalam proses belajar mengajar, sedangkan hasil belajar adalah output yang diharapkan ketika kompotensi dasar (materi pembelajaran) telah selesai diajarkan oleh dosen, dalam mengembangkan potensi peserta didik, dosen harus mampu mengelola komponen pembelajaran Bahasa Indonesia untuk 


\section{NIZHAMIYAH}

dipahamkan kepada peserta didik. Di setiap kegiatan pembelajaran tentunya mengharapkan tujuan pembelajaran tercapainya dengan harapan hasil yang sangat memuaskan. Namun ketika terdapat hasil mahasiswa yang tidak memuaskan seperti yang tidak diharapkan, tentunya mahasiswa tidak boleh disalahkan sepenuhnya, ada faktor yang menyebabkan hasil nilai mahasiswa rendah, baik faktor yang dalam keluarga maupun faktor yang berasal dari mahasiswa itu sendiri yaitu kurangnya minat belajar karna kurangnya hasil belajar yang kurang memuaskan. Dalam proses belajar mengajar kita dapat melihat peningkatan mutu pendidikan mahasiswa. Dosen sebagai salah satu pihak yang bertangung jawab dalam proses belajar mengajar mahasiswa dituntut mempersiapkan kegiatan proses belajar yang efektif dan efesien. Seorang dosen yang profesional memiliki kemampuan dalam menerapkan model pembelajaran yang efektif memahami model, terampil menggunakan model dalam pembelajaran. Karena salah satu faktor pendukung keberhasilan dosen dalam mengelola metode atau model belajar yang sesuai dengan materi yang diajarkan. Dalam proses belajar dosen harus melibatkan mahasiswa dalam pembelajaran, sehingga dapat meningkatkan kemauan mahasiswa dalam belajar, dan mahasiswa akan merasakan segala aktifitas dalam belajar menjadi pengalaman yang bermakna. Dosen bukan hanya sekedar menyampaikan materi, tetapi dosen lebih dari itu, dapat dikatakan sebagai sentral pembelajaran. Selain dosen, mahasiswa juga dituntut aktif dan kreatif dalam proses belajar mengajar. Dengan adanya pembelajaran dua arah antara dosen dan mahamahasiswa, maka hasil belajar akan maksimal. Tetapi kenyataannya sebagian dari dalam proses belajar Bahasa Indonesia kebanyakan cara dosen mengajar terlalu menoton dan menekankan pada penguasaan sejumlah konsep, sehingga konsep yang didapatkan tidak dapat bertahan lama, bahkan konsep yang diterapkan kurang mampu digunakan dalam keseharian dalam belajar, kebanyakan mahasiswa hanya menghapal tetapi tidak menerapkan disaat belajar, selebih itu mahasiswa lebih sering menjadi pendengar pasif, sementara dosen hanya menyampaikan pelajaran dengan mendikte dan menghapal dan memberi tugas mahamahasiswa, sehingga pelajaran Bahasa Indonesia menjadi 
sulit dimengerti akibatnya hasil belajar mahamahasiswa kurang maksimal dan tidak memuaskan.

\section{PEMBAHASAN}

\section{A. Pengertian Pembelajaran}

Pembelajaran adalah inti dari proses pendidikan secara keseluruhan dengan dosen sebagai pemengang peranan utama dan suatu proses yang terdiri dari kombinasi dua aspek, yaitu : belajar tertentu kepada apa yang harus dilakukan oleh mahasiswa, mengajar berorientasi pada apa yang harus dilakukan oleh dosen sebagai pemberi pelajaran. Kedua aspek ini akan berkolaborasi secara terpadu menjadi suatu kegiatan pada saat terjadi interaksi atara dosen dengan mahasiswa, serta antara mahasiswa dengan deengan mahasiswa disaat pembelajaran sedang berlangsung. Pembelajaran pada hakikatnya merupakan proses komunikasi antara peserta didik dengan pendidik serta antara peserta didikdalam rangka perubahan sikap. Karena baik konseptual maupun operasional konsep-konsep komunikasi dan perubahan sikapbakan selalu melekat pada pembelajaran. Zainal Arifin (2016:10) berpendapat "kata dasar "pembelajaran" adalah dalam arti sempit pembelajaran dapat diartikan sebagai suatu proses atau cara yang dilakukan agar seseorang dapat melakukan kegiatan belajar”. Suherman dalam Asep Jihat dan Abdul Haris (2013:11) "Pembelajaran pada hakikatnya merupakan proses komunikasi antara peserta didik dengan pendidik serta antara peserta didik dalam rangka perubahan sikap". Gagne dalam Mitftahul Huda (2014:3) “ Pembelajaran adalah sebagai proses modifikasi dalam kapasitas manusia yang bisa dipertahankan dan ditingkatkan levelnya". Dari penjelasan tersebut, maka dapat diartikan bahwa pembelajaran adalah kegiatan interaksi antara pendidikan dan peserta didik dalam memahami suatu yang mencapai tujuan.

\section{B. Pengertian Metode demonstrasi}

Pengertian dari metode demontrasi dan eksperimen, menurut Imas Kurniasih (2016:84) ialah sebuah upaya atau praktek dengan menggunakan peragaan yang ditujukkan pada mahasiswa agar semua mahasiswa lebih mudah dalam memahami dan mempraktekkan apa yang telah di peroleh dan didapatkan 
ketika berhasil mengatasi suatu permasalahan ketika ada perbedaan. Dalam kaitannya untuk proses pembelajaran, Metode Demonstrasi ialah metode mengajar dengan menggunakan peragaan untuk memperjelas suatu pengertian atau untuk memperlihatkan bagaimana berjalannya suatu proses pembentukan tertentu pada mahasiswa dan metode demonstrasi cukup baik apabila digunakan dalam penyampaian bahan pelajaran yang secara teknis banyak prakteknya, dan model pembelajaran demonstrasi ini juga bisa mempergunakan alat peraga, akan tetapi demonstrasi akan menjadi model yang tidak menarik apabila alat yang digunakan untuk mendemontrasikan tidak dapat diamati dengan seksama oleh mahasiswa. Dan model demonstrasi ini akan menjadi efektik bila mahasiswa terlibat langsung atau dapat mengikuti aktivitas tersebut, dan akan lebih menjadi pengalaman tersendiri yang tidak mudah dilupakan bagi mahasiswa.

\section{Hipotesis Penelitian}

Berdasarkan kerangka berpikir diatas maka hipotesis tindakan dalam penelitian ini adalah Ada pengaruh Metode Pembelajar Demonstrasi terhadap hasil belajar mahasiswa pada mata pelajaran Bahasa Indonesia mahasiswa PGSD Uiversitas Quality Medan.

\section{Metode penelitian}

\section{Jenis Penelitian}

Jenis penelitian ini adalah penelitian Metode Demonstrasi, yaitu penelitian yang bertujuan untuk mengetahui ada tidaknya pengaruh dari hasil belajar dari metode demonstrasi memperlihatkan langsung. Sampel yang akan diambil dalam penelitian ini terdiri dari dua yaitu kelas Ekperimen dan kelas kontrol, kedua kelas ini mendapatkan perlakuan yang berbeda.

\section{Lokasi Penelitian dan Waktu Penelitian}

Lokasi Penelitian ini adalah di Mahasiswa PGSD Universitas Quality semester 1 Tahun Akademik 2019/2020, Adapun yang menjadi alasan peneliti memilih lokasi ini adalah karena penulis merupakan dosen pada mata kuliah Bahasa Indonesia di Universitas Quality Medan. 


\section{Populasi Dan Sampel Penelitian}

\section{a. Populasi}

Populasi peneltian ini adalah mahasiswa semester 1 kelas A22 dan A23 yang berjumlah 66 orang.

\begin{tabular}{|c|c|}
\hline Kelas & Jumlah (orang) \\
\hline VA & 34 \\
\hline VB & 32 \\
\hline Total & 66 \\
\hline
\end{tabular}

\section{b. Sampel}

Sampel adalah bagian dari populasi yang dipandang dapat mewakili seluruh populasi yang ada dalam peneliti. Maka sampel dalam peneliti ini merupakan total unit populasi dalam dua kelas, kelas A22 dan A23 yang berjumlah 66 orang.

Desain penelitian yang digunakan adalah desain yang menggunakan pre test dan pos test yang ditunjukkan pada tabel. Desain ini merupakan yang paling efektif dalam istilah penunjukan sebab akibat. Desain ini melengkapi kelompok kontrol maupun pengukuran perubahan tetapi juga menambahkan suatu pre test untuk menilai perbedaan antara dua kelompok sebelum studi dilakukan.

\section{Tabel Sebaran Sampel}

\begin{tabular}{|c|c|}
\hline Kelas IPA & Bayak Siswa \\
\hline $\mathrm{X} 1$ & 34 \\
\hline $\mathrm{X} 2$ & 32 \\
\hline
\end{tabular}

Keterangan :

$X_{1}=$ Model Pembelajaran Metode Demonstrasi

$X_{2}=$ Pembelajaran Konvesional 


\section{Prosedur Penelitian}

Untuk melaksanakan penelitian ini tahap-tahap yang dilaksanakan adalah sebagai berikut :

\section{a. Tahap Persiapan}

Kegiatan yang dilakukan dalam tahap ini meliputi persiapanpersiapan hubungan dengan pelaksanaan penelitian.

1) Menyusun instrument wawancara, aktivitas dan pengetahuan konseptual siswa.

2) Menyusun rencana pembelajaran semester (RPS) Bahasa Indonesia dengan pokok bahasan Materi EYD dengan metode pembelajaran Demonstrasi.

3) Mempersiapkan alat peraga pembelajaran

4) Menentukan kelas sampel dari populasi yang ada

\section{b. Tahap Pelaksanaan}

1) Melaksanakan Pre test Peneliti memberikan soal Pre test pada siswa sebelum pokok bahasan diajarkan untuk mengetahui kemampuan awal mahasiswa.

2) Melakukan pengajaran pada kedua kelas yaitu:

a) Pada kelas eksperimen adalah Mata kuliah Bahasa indonesia materi Materi EYD dengan menggunakan model pembelajaran Metode Demonstrasi

b) Pada kelas kontrol adalah Pengajaran pengajaran Bahasa Indonesia Materi EYD dengan menggunakan model pembelajaran Konvesional.

3) Melaksanakan Post test

Setelah pembelajaran selesai, peneliti akan melakukan post testuntuk mengetahui kemampuan akhir siswa pada kelas eksperimen dan kelas kontrol. 
4) Melakukan pengolahan data pre test dan post test

5) Melakukan analisis data pre test Yaitu uji normalitas, uji homogenitas, dan uji baris kolom (bk) pre test siswa pada kelas eksperimen dan kelas kontrol.

6) Melakukan analisis data post test yaitu uji normalitas, uji homogenitas, uji t, pada kelas eksperimen dan kelas kontrol. Kemudian dilakukan uji hipotesis.

7) Setelah uji hipotesis dapat diambil kesimpulan.

\section{Uji Hipotesis Penelitian}

Setelah data hasil belajar kedua kelompok diperoleh maka dilakukan analisis data untuk mengetahui perbedaan kedua kelompok tersebut. Untuk mengetahui apakah perbedaan hasil belajar kedua kelompok signifikan atau tidak dilakukan analisis statistik. Adapun langkah-langkah analisisnya adalah sebagai berikut:

Hipotesis penelitian di semester 1 mahasiswa PGSD Universitas Quality Medan dapat dirumuskan dalam $H_{0}$ dan $H_{1}$ sebagai berikut :

$\mathrm{H}_{0}: \rho=0 \quad$ (Tidak ada pengaruh metode pembelajaran demonstrasi terhadap hasil belajar mahasiswa pada Mata Pelajaran Bahasa Indonesia Materi EYD Tahun Akademik 2019/2020. $\mathrm{H}_{1}: \rho \neq 0$ (Ada pengaruh metode pembelajaran demonstrasi terhadap hasil belajar mahasiswa pada Mata Pelajaran Bahasa Indonesia Materi EYD Tahun Akademik 2019/2020

\section{a. Uji Normalitas Data}

Uji normalitas data dilakukan untuk mengetahui apakah sampel yang diteliti sudah berdistribusi normal, uji normalitas yang digunakan adalah uji Chi-Squares atau distribusi chikuadrat. Sudjana (2013: 147) menyatakan "Distribusi chikuadrat merupakan distribusi dengan variabel acak kontinu”. Uji 
normalitas data disajikan secara berkelompok. Data berbentuk nominal atau ordinal.

Hipotesis normalitas data adalah :

$\mathrm{H}_{\mathrm{o}}$ : Data berdistribusi normal

$\mathrm{H}_{1}$ : Data tidak berdistribusi normal

Sudjana (2013:273) menyatakan rumus untuk menguji normalitas data adalah :

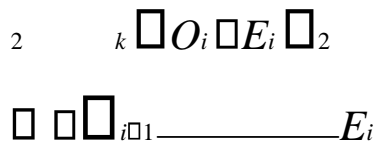

Keterangan :

$$
\begin{array}{ll}
\mathrm{Oi} & =\text { Frekuensi hasil pengamatan pada klasifikasi ke-i } \\
\mathrm{E}_{\mathrm{i}} & =\text { Frekuensi yang diharapkan pada klasifikasi ke-i } \\
\chi^{2} & =\text { Chi-Square } \\
\mathrm{k} & =\text { Banyak kelas }
\end{array}
$$

Kriteria Uji: Terima $H_{0}$ jika $\chi^{2}<\chi\left({ }^{2} 1-\alpha\right)(k-3)$ pada Tingkat signifikan $(\alpha)=$

$5 \%=0,05$ dengan derajat kebebasan $(\mathrm{dk})=\mathrm{k}-3$

Sehingga kriteria pengujian chi-kuadrat untuk data yang telah disusun dalam daftar distribusi frekuensi adalah terima $\mathrm{H}_{1}$ jika $\chi^{2}$ $\geq\left({ }^{2} 1-\alpha\right)(k-1)$ dengan $\alpha=$ taraf nyata untuk pengujian. Dalam hal lainnya, $\mathrm{H}_{0}$ diterima.

\section{b. Homogenitas Varians}

Setelah data berdistribusi normal kemudian dapat dilanjutkan dengan uji homogenitas. Untuk menguji homogenitas varians dari dua kelompok data digunakan Uji F.

1) Rumusan hipotesis menurut Sudjana (2013: 250) yaitu:

$$
\begin{array}{ll}
\mathrm{H}_{0} & : \sigma_{12}=\sigma 22 \\
\mathrm{H}_{1} & : \sigma_{12} \neq \sigma_{22}
\end{array}
$$


Rumus untuk uji F adalah:

$$
F=\frac{\text { Varians terbesar }}{\text { Varians terkecil }}
$$

Kriteria Pengujian hipotesis $: \mathrm{H}_{0}$ ditolak jika $\mathrm{F} \geq \mathrm{F}(1,2)$

Dengan $\square_{1}=n_{1}-1$ dan $\square_{2}=n_{2}-1$

Keterangan $: \square_{1}=$ derajat bebas pembilang

$\square 2=$ derajat bebas penyebut

Untuk mengetahui persamaan regresi linier Untuk mengetahui persamaan regresi linier $\mathrm{Y}$ dan $\mathrm{X}$ telah ditentukan dan sudah didapat koefisien arah $b$, maka koefisien determinasi $r^{2}$ dapat ditentukan oleh rumus :

\section{c. Uji Independen Antara Dua Faktor}

rumus : $x^{2}=\sum_{i=j}^{B} \sum_{j=i}^{K}\left(\frac{O_{i j-} E_{i j}}{E_{i j}}\right)^{2}$

Dengan:

$E_{i j}=\left(n_{i o} \times n_{o i}\right) / n$

Keterangan:

$n_{i o}=$ jumlah baris ke-i

$n_{o i}=$ jumlah kolom ke-j

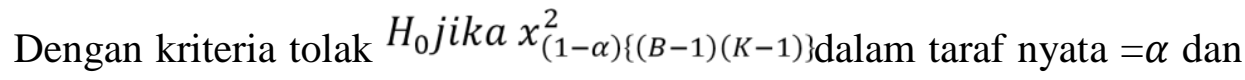
derajat

kebebasan dk untuk distribusi Chi-kuadrat $=(B-1)(K-1)$.

Terlebih dahulu dilakukan pengujian normalitas data dan homongens varians. Menurut Sugiyono (2017:210) bahwa "Statistik parameitris memerlukan banyak asumsi yang dipengaruhi, Asumsi yang utama adalah data yang akan dianalisis harus berdistribusi normal. Selanjutnya dalam penggunaan salah satu tas mengharuskan data dua kelompok atau lebih yang diuji harus homongen". 
Berikut ini adalah rumus uji normalitas data yang disajikan secara berkelompok.

Data berbentuk nominal atau ordinal.

\section{E. Hasil Penelitian}

\section{Pengujian Hipotesis}

Pengujian hipotesis pada penelitian ini menggunakan rumus Uji Independent Antara Dua Faktor. Sebelum melalukukan pengujian maka, terlebih dahulu dicari uji persyaratan analisis data uji normalitas homogenitas varians.

\section{a. Analisis Data PresTest}

$P$
\begin{tabular}{|l|l|}
\hline Kelas & Rata-rata Nilai Akhir Siswa \\
\hline$e^{\mathrm{Va}}$ & 80,13 \\
\hline
\end{tabular}

test atau tes awal dilakukan untuk melihat kemampuan awal siswa dari dua kelas yitu 2A22 dan 2A23. Oleh karna itu pengujian yang dilakukan terhadap hasil prestet adalah uji normalitas, uji homongenitas dan uji persamaan rata-rat pretest pada kelas yang diajarkan untuk mengatahui kesetaraan hasil belajar mahasiswa.

\section{1) Uji Normalitas Data Awal}

Uji normalitas data untuk dua kelas sampel kelas 2A22 dan 2A23 yaitu dihitung dengan menggunakan uji Chi squares seperti berikut :

Dari perhitungan untuk Pretest pada kelas Va, Uji normalitas

\begin{tabular}{|c|c|c|c|c|}
\hline $\mathrm{D}_{\text {Kelas }}$ & $x_{2 \text { hitung }}$ & $\begin{array}{c}2 \\
X_{\text {tabel }}\end{array}$ & Kelas & Tafsiran \\
\hline S Demonstrasi VA & 1,21 & 7,81 & $\mathrm{Va}$ & Normal \\
\hline $\begin{array}{l}\text { Pembelajaran } \\
\text { Konvensional } \\
\text { i VB }\end{array}$ & 0,71 & 7,81 & $\mathrm{Vb}$ & Normal \\
\hline
\end{tabular}

busi Frekuensi diperoleh chi-square $\left(x^{2}\right)$ hitung $=1,21$ sedangkan chisquare $\left(x^{2}\right)$ tabel $=7.81$ dengan $\mathrm{dk}=3$. Pada taraf kepercayaan $95 \%$. Hal ini menunjukan chi-square $\left(x^{2}\right)$ hitung $<$ chi-square $\left(x^{2}\right)$ tabel. 
Dengan demikian dapat disimpulkan bahwa data pretest pada kelas 2A22 berdistribusi normal.

Dari perhitungan untuk Pretest pada kelas $\mathrm{Vb}$, Uji normalitas Distribusi Frekuensi diperoleh chi-square $\left(x^{2}\right)$ hitung $=0,71$ sedangkan chi-square $\left(x^{2}\right)$ tabel $=7.81$ dengan $\mathrm{dk}=3$. Pada taraf kepercayaan $95 \%$. Hal ini menunjukan chi-square $\left(x^{2}\right)$ hitung $<$ chisquare $\left(x^{2}\right)$ tabel. Dengan demikian dapat disimpulkan bahwa data pretest pada kelas 2A23 berdistribusi normal.

\section{2) Uji Homogenitas Data Pretest}

Uji homogenitas dilaksanakan untuk mengetahui apakah kedua data tersebut mempunyai varians yang sama atau berbeda. Setelah dilaksanakan uji normalitas data, selanjutnya dilaksanakan uji homongenitas untuk mengetahui populasi varians. Hasil perhitungan untuk uji homongenitas dapat dilihat di tabel

\section{Hasil Uji Homogenitas Data Pretest}

\begin{tabular}{|c|c|c|c|c|c|c|}
\hline Data & Kelas & $\mathrm{N}$ & Varians & $F_{\text {hitung }}$ & $F_{\text {tabel }}$ & Keterangan \\
\hline \multirow{4}{*}{ Pretest } & Va (kelas & \multirow{2}{*}{34} & \multirow{2}{*}{6,72} & \multirow{4}{*}{0,96} & \multirow{4}{*}{1,81} & \\
\hline & Eksperimen) & & & & & Artinya \\
\hline & Vb (kelas & \multirow[t]{2}{*}{32} & \multirow[t]{2}{*}{6,60} & & & $\begin{array}{l}\text { Varians } \\
\text { homo }\end{array}$ \\
\hline & kontrol) & & & & & Ngen \\
\hline
\end{tabular}

Pada tabel di atas, diketahui $\mathrm{F}_{\text {hitung }}=0,96$ dengan $\mathrm{dk}_{1}=\mathrm{n}_{1}$ dan $\mathrm{dk}_{2}=\mathrm{n}_{2}$ 1 pada taraf kepercayaan 95\% maka hasil menggunakan program di MS-Excel dengan rumus $=F \operatorname{INV}(0,05 ; 33,31)$ diperoleh $F_{\text {tabel }}=1,81$.

Diterima $\mathrm{F}_{\text {hitung }}<\mathrm{F}_{\text {tabel }}$ sehingga dapat diasumsikan bahwa data pretest kelas 2A22 dan 2A23 berasal dari populasi dengan varians yang sama (Homogen). 


\section{3) Uji Data Pretest}

Dari uji normalitas dan homogenitas yang telah dilakukan sebelumnya didapat kesimpulan data pre test dari kedua sampel yaitu kelas 2A22 dan 2A23 berdistribusi normal dan berasal dari populasi dengan varians yang sama. Tahap berikutnya, yaitu dengan melakukan uji $\mathrm{t}$ untuk melihat aoakah kedua sampel memiliki rata-rat yang sama dengan menguji signifikasi perbedaan rata-rata dari prhitungan uji t Hasil Uji t Data Pre Test

\begin{tabular}{|l|c|c|}
\hline & Kelas Va & Kelas Vb \\
\hline Jumlah Sampel $(\mathrm{n})$ & 34 & 32 \\
\hline Standar Deviasi (s) & 6,6 & 6,72 \\
\hline $\begin{array}{l}\text { Standar Deviasi } \\
\text { Gabungan }\end{array}$ & 35,54 & 33,04 \\
\hline Rata-rata $(\mathrm{x})$ & \multicolumn{2}{|c|}{1,154} \\
\hline Thitung & \multicolumn{2}{|c|}{1,81} \\
\hline Ttabel & \\
\hline
\end{tabular}

Berdasarkan uji t pada tabel 4.13 menggambarkan bahwa data nilai pretest dari kelas 2A22 dan 2A23 dapat nilai thitung sebenarnya 1,154 nilai $\mathrm{t}_{\text {tabel }}$ pada $\mathrm{dk}=46$ pada derajat kepercayaan $95 \%$ diperoleh sebenarnya 1,81 . Hal ini

menunjukkan bahwa $\mathrm{t}_{\text {hitung }}<\mathrm{t}_{\text {tabel }}$ sehingga perlakuan atau $\mathrm{H}_{0}$ diterima.

\section{4) Analisis Data Postest}

Uji normalitas data postest masukkan untuk mengetahui nilai akhir yang diperoleh siswa setelah pemberian materi kepada kelas yang berbeda menggunakan model yang bebeda. Mengacu pada aturan analisis data post test, maka analisis data post test diperoleh sebagai berikut. 


\section{Uji Normalitas Data}

Hasil uji normalitas data post test pada kelas 2A22 dan 2A23 terlihat pada tabel

\begin{tabular}{|l|l|l|l|}
\hline Kelas & thitung & tabel & Tafsiran \\
\hline VA & 6,14 & 7,81 & Normal \\
\hline VB & 0,52 & 7,81 & Normal \\
\hline
\end{tabular}

\section{Hasil Normalitas Data Postest}

Dari perhitungan untuk Postest pada kelas 2A22, Uji normalitas Distribusi Frekuensi diperoleh harga chi-square $\left(x^{2}\right)$ hitung $=6,14$ sedangkan chi-square $\left(\mathrm{x}^{2}\right)$ tabel, $=7,81$ dengan $\mathrm{dk}=3$ pada tarif kepercayaan $95 \%$. Untuk perhitungan postest pada kelas 2A23, Uji norrmalitas Distribusi frekuensi diperoleh harga chi-square $\left(x^{2}\right)$ hitung $=0,52$ sedangkan chi-square $\left(\mathrm{x}^{2}\right)$ tabel $=7,81$ dengan $\mathrm{dk}=3$ pada taraf kepercayaan $95 \%$. Hal ini menunjukkan chi-square $\left(\mathrm{x}^{2}\right)$ hitung $<$ $\left(\mathrm{x}^{2}\right)$ tabel. Dengan demikian dapat disimpulkan bahwa data postest pada kelas 2A22 dan 2A23 berdistribusi normal.

\section{Uji Homogenitas Varians}

Setelah dilakukan uji normalitas data, selanjutnya dilakukan Uji homongenitas data postest untuk mengetahui populasi varians yaitu untuk mengetahui apakah data tersebut mempunyai varians yang sama atau berbeda. Hasil perhitungan untuk uji homongenitas data postest dapat dilihat pada tabel dibawah ini. 


\section{Homogenitas Postest}

\begin{tabular}{|c|c|c|l|l|l|l|}
\hline Data & Kelas & $\mathbf{N}$ & Varians & $F_{\text {hitung }}$ & $F_{\text {tabel }}$ & Keterangan \\
\hline Pretest & $\begin{array}{l}\text { Va (kelas } \\
\text { Eksperimen) }\end{array}$ & 34 & 8,86 & 33,03 & 5,99 & \begin{tabular}{l} 
Fhitung $<$ Ftabel \\
$\begin{array}{l}\text { Artinya } \\
\text { kedua } \\
\text { Varians } \\
\text { homo } \\
\text { Ngen }\end{array}$ \\
\hline
\end{tabular} \\
$\begin{array}{l}\text { Vb (kelas } \\
\text { kontrol) }\end{array}$ & 32 & 8,06 & & & & \\
\hline
\end{tabular}

Pada tabel di atas, diketahui $\mathrm{F}_{\text {hitung }}=33,03$, dengan $\mathrm{dk}_{1}=\mathrm{n}_{1}-1$ dan $\mathrm{dk}_{2}=$ $\mathrm{n}_{2}-1$ pada taraf kepercayaan $95 \%$ maka hasil interpolasi diperoleh $\mathrm{F}_{\text {tabel }}=5$,99. Dimana $\mathrm{F}_{\text {hitung }}<\mathrm{F}_{\text {tabel }}$ sehingga dapat diasumsikan bahwa data postest kelas 2A22 dan 2A33 berasal dari populasi dengan varians yang sama (homongen).

\section{Uji Hipotesis}

Setelah data postest semester 1 mahasiswa PGSD sudah berdistribusi normal dan homongen maka dilakukan pengujian hipotesis dengan menggunakan ujiindenpendent antara dua faktor. Untuk melihat hasil uji indenpendent anatara dua faktor anatara kedua kelas dapat dilihat pada tabel berikut.

\section{Tabel Hasil Uji Indenpendent Antara Dua Faktor}

\begin{tabular}{|l|l|l|l|l|}
\hline Kelas & $\mathrm{B}$ & $\mathrm{K}$ & $\mathrm{x} 2$ & $\mathrm{x}_{2(0,95 \mathrm{X} 3)}$ \\
\cline { 1 - 5 } Demonstrasi & 2 & 3 & 16,32 & 7,81 \\
\cline { 1 - 3 } Konvensional & & & & \\
\hline
\end{tabular}

Berdasarkan perhitungan statistik uji indenpendent anatara dua faktor untuk kelas $2 \mathrm{~A} 22$ dan $2 \mathrm{~A} 23$ dan $\mathrm{dk}=3$. Dengan kriteria pengujian hipotesis bahwa $\mathrm{x}_{2}(1-\alpha)$ untuk $\alpha=5 \%$ dengan dk untuk distribusi chikuadrat $=(\mathrm{B}-1)(\mathrm{K}-1)$, dan maka, $\mathrm{H}_{0}$ ditolak dan $\mathrm{H}_{1}$ diterima. Maka dapat disimpulkan bahwa dengan menggunakan model pembelajaran Demonstrasi ada pengaruh terhadap hasil belajar mahasiswa pada mata kuliah Bahasa Indonesia. 


\section{DAFTAR PUSTAKA}

Aripin, Zainal.2016. Evaluasi Pembelajaran: Prinsip, Teknik, danProsedur. Bandung: PT. Remaja Rosdakarya.

Huda, Miftahul. 2014. Model-model Pengajarandan

Jihat, Asepdan Abdul Haris. 2013. Evaluasi pembelajaran, Yogyakarta: Multi Persindo

Kurniasih, Imasdan Berlin Sari. 2016. Model-model Pengajaran dan pembelajar,.Bandung: Kata Pena

Pembelajaran. Yogyakarta: Pustaka Belajar

Sudjana. 2013. Metode Statistika. Bandung: Tarsito.

Sugiyono.2017. Metode Penelitian Pendidikan. Bandung: Alpabeta. 